Удк 665.572.9:543.544.45

\title{
КОМПОНЕНТНЫЙ СОСТАВ ЭФИРНОГО МАСЛА ПОЛЫНИ СОЛЯНКОВИДНОЙ (ARTEMISIA SALSOLOIDES WILLD) И ЕГО АНТИМИКРОБНЫЕ СВОЙСТВА
}

\author{
(C) Е.З. Лапкина ${ }^{1 *}$, Т.К. Захарова ${ }^{2}$, Л.С. Тирранен ${ }^{1}$ \\ ${ }^{1}$ Федеральный исследовательский центр - Красноярский научный центр \\ СО РАН, ул. Академгородок, 50, Красноярск, 660036 (Россия), \\ e-mail: e.z.lapkina@mail.ru \\ ${ }^{2}$ Красноярский государственный медицинский университет им. профр. \\ В.Ф. Войно-Ясенецкого, ул. Партизана Железняка, 1, Красноярск, 660022 \\ (Россия)
}

\begin{abstract}
Цель данной работы - определение компонентного состава, антимикробных свойств эфирного масла и выявление анатомических особенностей стеблей и листьев растений Artemisia salsoloides.

Растения Artemisia salsoloides собирали в Волгоградской области по долинам рек Иловли и Дона. Эфирное масло извлекали методом исчерпывающей гидропародистилляции, а его компонентный состав определяли методом хромато-масс-спектрометрии.

Антимикробную активность эфирного масла оценивали по реакции тест-бактерий (Acinetobacter baumannii, Escherichia coli, Klebsiella pneumoniae, Pseudomonas aeruginosa, Staphylococcus aureus) в 5-кратной повторности по разнице в размерах диаметра колоний тест-бактерий в опыте и контроле (тест-бактерии, соединенные с 0,5 мл дистиллированной воды).

В результате исследований в составе эфирного масла обнаружены 24 компонента, среди которых превалируют: лимонен (34,8\%), транс- $\beta$-оцимен $(20,4 \%)$, цис- $\beta$-оцимен $(12 \%), \alpha$-пинен $(7,2 \%), \beta$-мирцен $(6,3 \%), \beta$-пинен $(6,2 \%)$. Обнаружено достоверное стимулирующее действие эфирного масла полыни солянковидной на рост колоний Escherichia coli $(\mathrm{p}<0,05)$, Klebsiella pneumoniae $(\mathrm{p}<0,01)$, индифферентное действие - на рост колоний Staphylococcus aureus, Pseudomonas aeruginosa, Acinetobacter baumannii. Выявлены анатомические особенности стебля и листа Artemisia salsoloides Willd: смоляные ходы в латеральных частях среза листа, секреторные каналы в эндодерме стебля, эфирномасличные вместилища в мезофилле листа, липидные капли в клетках хлоренхимы.

Ключевые слова: антимикробная активность, эфирное масло, полынь солянковидная, анатомия растений.
\end{abstract}

\section{Введение}

Род Artemisia L. объединяет свыше 200 видов растений. На территории России и сопредельных стран произрастает около 180 видов. Большинство из них являются эфирномасличными растениями. Artemisia absinthium L., Artemisia dracunculus L. культивируются и находят свое применение в различных областях жизнедеятельности человека [1]. В настоящее время важной задачей является поиск новых противомикробных лекарственных средств растительного происхождения. Эфирные масла растений - природные источники большого набора биологически активных веществ, обладающих бактерицидными свойствами. У разных растений эти свойства выражены в различной степени [2, 3]. Проведенные многочислен-

Лапкина Екатерина Зиядхановна - кандидат

биологических наук, инженер,

e-mail: e.z.lapkina@mail.ru

Захарова Тамара Кузьминична - кандидат

биологических наук, доцент, e-mail: zax20111985@mail.ru

Тирранен Ляля Степановна - доктор биологических наук, ведущий научный сотрудник, e-mail: 1-tiran@ya.ru ные исследования доказали наличие у эфирных масел антибактериальной, противогрибковой, антивирусной, противоопухолевой, антиоксидантной активности [4-6]. Есть сведения о том, что настойки полыни обладают антибактериальной активностью против грамположительных микроорганизмов и нетоксичны для макроорганизма [7].

\footnotetext{
* Автор, с которым следует вести переписку.
} 
Санационный эффект воздуха помещений наблюдается у эфирного масла полыни горькой (снижение обсемененности сразу после санации на $17 \%$ и на $35 \%$ - после 12 ч санации относительно первоначального уровня) [8]. Эфирные масла полыней Artemisia obtusiloba Ledeb., Artemisia santolinifolia Turcz. ex Bess., Artemisia glauca Pall. ex Willd., Artemisia sieversiana Willd. обладают антибактериальным действием по отношению к S. epidermidis, S. aureus, E. Coli [9]. Эфирное масло в дозе 6 мг/мл, извлеченное из сырья Artemisia annиа L. проявляет бактерицидное действие к Staphylococcus aureus [3].

Oсобое внимание следует уделять изучению компонентного состава растений рода Artemisia L. из-за входящих в состав эфирных масел некоторых полыней токсичных веществ (чаще $\alpha$ - и $\beta$-туйоны) [1]. В Волгоградской области по долинам рек Иловли, Дона произрастает Artemisia salsoloides Willd, характерное растение меловых обнажений, современный ареал которого имеет реликтовый характер и связан с зоной опустыненных и дерновинно-злаковых степей [10]. Компонентный состав эфирного масла Artemisia salsoloides и его антимикробные свойства остаются неизученными. Так как продукты вторичного обмена накапливаются в специализированных структурах органов растений [11], необходимо анатомическое исследование основных надземных вегетативных органов растений Artemisia salsoloides.

Цель исследований: определить компонентный состав, антимикробные свойства эфирного масла и выявить анатомические особенности стеблей и листьев растений Artemisia salsoloides.

\section{Экспериментальная часть}

Объектом исследования являлись растения Artemisia salsoloides, произрастающие в Волгоградской области по долинам рек Иловли и Дона.

Для получения эфирного масла исследуемое сырье собирали в фазе конца цветения - начала плодоношения согласно ГОСТ 31145-94. Эфирное масло извлекали из мелкоизрубленной надземной части методом исчерпывающей гидропародистилляции в течение 12-14 ч. Компонентный состав эфирного масла определяли методом хромато-масс-спектрометрии на газовом хроматографе Agilent Technologies 7890 A с квадрупольным масс-спектрометром Agilent Technologies 5975 C [12]. Содержание компонентов оценивали по площадям пиков, а идентификацию отдельных компонентов производили на основе совпадения полных масс-спектров и линейных индексов удерживания определяемых компонентов с имеющимися литературными данными [13]. Плотность и показатель преломления полученного эфирного масла определяли с использованием высокоточных приборов фирмы Mettler Toledo RE 40D и Mettler Toledo RE 400 соответственно.

Антимикробную активность эфирного масла оценивали по реакции тест-бактерий (Acinetobacter baumannii, Escherichia coli, Klebsiella pneumoniae, Pseudomonas aeruginosa, Staphylococcus aureus) в 5 кратной повторности по разнице в размерах диаметра колоний тест-бактерий в опыте и контроле $[14,15]$. Контролем служили тест-бактерии, соединенные с 0,5 мл дистиллированной воды. Воздействие эфирного масла на тест-культуру оценивали как стимулирующее, ингибирующее, индифферентное, когда размер колоний тест-культур в опыте был, соответственно, достоверно увеличен, снижен или достоверно не изменен по сравнению с контролем. Результаты исследований обработали статистически с использованием критерия Стьюдента для 95\% и 99\% уровней значимости [16]. Для анатомического исследования использовали наземные части растения (лист и стебель), которые помещали в 95\% этиловый спирт. Для выявления жироподобных включений срезы обрабатывали раствором судана. Обработанные срезы помещали в глицерин и изучали с помощью светового микроскопа.

\section{Обсуждение результатов}

Полученное эфирное масло полыни солянковидной представляет собой жидкость зеленого цвета легче воды (плотность $-0,8505$ г $\mathrm{cm}^{3}$ ), показатель преломления - 1,4874. Превалирующими в составе эфирного масла Artemisia salsoloides являются 6 компонентов из 23 идентифицированных веществ (табл. 1). Определены основные компоненты эфирного масла: лимонен $(34,8 \%)$, транс- $\beta$-оцимен $(20,4 \%)$, иис- $\beta$ оцимен (12\%), $\alpha$-пинен (7,2\%), $\beta$-мирцен (6,3\%), $\beta$-пинен $(6,2 \%)$.

Результаты исследований показывают, что эфирные масла растений полыни значительно отличаются по своему химическому составу. 
Во многих видах полыней (A. lerchiana, A.santonica, A. austriaca, A. frigida) основным компонентом эфирного масла является камфора (33-74\%) [17, 18]. В Artemisia salsoloides преобладает лимонен (34,8\%), отсутствующий в вышеуказанных видах полыней.

Выявлено достоверное стимулирующее действие эфирного масла полыни солянковидной (Artemisia salsoloides) на рост колоний Escherichia coli $(\mathrm{p}<0,05)$, Klebsiella pneumoniae (p <0,01) (табл. 2).

В остальных случаях выявлено только индифферентное действие эфирного масла Artemisia salsoloides.

Использованный способ определения действия эфирного масла на рост тест-микроорганизмов позволил выявить достоверное стимулирующее действие на рост Escherichia coli и Klebsiella pneumoniae, в то время как при использовании диско-диффузного метода, применявшийся в исследованиях действия на микроорганизмы эфирных масел растений большинством авторов [19], не указаны ни достоверные результаты, ни их уровни значимости. По литературным данным, кокковые и палочковидные бактерии (Staphylococcus aureus, Yersinia enterocolitica, Eschrichia coli) обладали невысокой чувствительностью к настоям полыни (A. glauca, A. macrantha, A. commutate, A. laciniata, A. latifolia A. pontica). Ввиду отсутствия в диско-диффузном методе контроля невозможно вычислить $\mathrm{t}_{\text {studenta }}$ в опыте и сравнить $\mathrm{c}_{\text {studenta }}$ табличным [16]. Не представляется возможной оценка достоверности полученных результатов и уровнях значимости.

Таблица 1. Компонентный состав эфирного масла Artemisia salsoloides

\begin{tabular}{|c|c|c|c|c|}
\hline № ח/П & RT, мин. & RI & Компонент & $\begin{array}{c}\text { Содержание, \% } \\
\text { от цельного масла }\end{array}$ \\
\hline 1 & 7,40 & 932 & $\alpha$-Пинен & 7,2 \\
\hline 2 & 8,66 & 973 & Сабинен & 0,5 \\
\hline 3 & 8,76 & 975 & $\beta$-Пинен & 6,2 \\
\hline 4 & 9,28 & 991 & $\beta$-Мирцен & 6,3 \\
\hline 5 & 10,63 & 1028 & Лимонен & 34,8 \\
\hline 6 & 10,93 & 1038 & циис- $\beta$-Оцимен & 12,0 \\
\hline 7 & 11,32 & 1048 & транс- $\beta$-Оцимен & 20,4 \\
\hline 8 & 11,60 & 1058 & $\gamma$-Терпинен & 0,2 \\
\hline 9 & 12,61 & 1088 & $\alpha$-Терпинолен & 0,2 \\
\hline 10 & 12,94 & 1098 & Розфуран & 0,2 \\
\hline 11 & 14,05 & 1129 & Алло-оцимен & 0,3 \\
\hline 12 & 15,74 & 1144 & ццис- $\beta$-Терпинеол & 0,3 \\
\hline 13 & 16,21 & 1162 & не идентифицирован & 0,4 \\
\hline 14 & 17,19 & 1219 & Карвеол & 0,6 \\
\hline 15 & 18,05 & 1245 & Карвон & 0,3 \\
\hline 16 & 19,48 & 1284 & Бензилацетилен & 5,5 \\
\hline 17 & 22,70 & 1304 & Геранилформиат & 1,0 \\
\hline 18 & 25,70 & 1352 & $\alpha$-Лонгипинен & 0,2 \\
\hline 19 & 25,77 & 1485 & Ar-куркумен & 0,4 \\
\hline 20 & 26,20 & 1498 & Капиллен & 0,5 \\
\hline 21 & 27,00 & 1524 & $\beta$-Сесквифелландрен & 1,1 \\
\hline 22 & 28,60 & 1580 & Спатуленол & 0,8 \\
\hline 23 & 31,86 & 1703 & Геранилтиглат & 0,2 \\
\hline 24 & 32,79 & 1730 & Хамазулен & 0,4 \\
\hline \multicolumn{4}{|c|}{ ИТОГО: } & 100,0 \\
\hline
\end{tabular}

Примечание. RI - линейный индекс удерживания, рассчитываемый автоматически по программе AMDIS.

Таблица 2. Влияние эфирного масла полыни солянковидной Artemisia salsoloides на рост колоний тестмикроорганизмов (мм)

\begin{tabular}{l|c|c|c}
\hline Наименование тест-микроорганизмов & Контроль & Опыт & $\mathrm{t}_{\text {разности }}{ }^{*}$ \\
\hline Escherichia coli & $9,4 \pm 0,27$ & $10,2 \pm 0,12$ & 2,72 \\
Pseudomonas aeruginosa & $10,2 \pm 0,12$ & $9,8 \pm 0,24$ & 1,50 \\
Klebsiella pneumoniae & $8,2 \pm 0,24$ & $9,8 \pm 0,12$ & 6,00 \\
Staphylococcus aureus & $6,6 \pm 0,42$ & $6,4 \pm 0,18$ & 0,14 \\
Acinetobacter baumannii & $8,8 \pm 0,24$ & $9,2 \pm 0,12$ & 1,50 \\
\hline
\end{tabular}

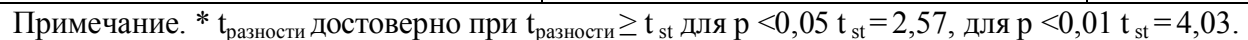


При анатомическом исследовании листьев и стеблей растений Artemisia salsoloides обнаружены признаки эфирномасличного растения. Поперечный срез листа имеет овальную форму, тип листа изолатеральный. Покровная ткань листа - эпидерма, представлена одним рядом крупных клеток и толстым слоем кутикулы. Клетки верхней и нижний эпидермы со слабоизвилистыми стенками, плотно прилегающими друг к другу. Устьица расположены на верхней и нижней эпидерме, непогруженные, аномоцитного типа. Мезофилл листа слабо дифференцирован на губчатый и столбчатый слои. В мезофилле встречаются эфирномасляничные вместилища. Проводящие пучки коллатеральные, 4 мелких и 1 крупный сосудистоволокнистый проводяший пучок. Середина листа представлена бесцветной паренхимой с клетками округлой формы. В латеральных частях среза листовой пластинки расположены 1-2 смоляных хода. Стебель на поперечном срезе имеет округлую форму с ребрами. Покровная ткань представлена однослойной эпидермой с клетками округлой формы. Эндодерма примыкает к пучкам с наружной стороны, имеет 6 секреторных каналов и липидные капли в клетках хлоренхимы. Имеется 12-13 коллатеральных проводящих пучков, расположенных по кольцу близко друг к другу. Основную часть пучка занимает ксилема, на границе с ней слой древесины. Межпучковая зона представлена паренхимой. Сердцевина из неодревесневающих клеток округлой формы, плотно прилегающих друг к другу, без воздушной полости.

Таким образом, впервые изучен компонентный состав эфирного масла полыни солянковидной и проведена достоверная оценка его антимикробных свойств.

\section{Bbводы}

1. Эфирное масло полыни солянковидной содержит 24 компонента, из них основными являются: лимонен (34,8\%), транс- $\beta$-оцимен (20,4\%), циис- $\beta$-оцимен (12\%), $\alpha$-пинен $(7,2 \%), \beta$-мирцен $(6,3 \%), \beta$-пинен $(6,2 \%)$.

2. Установлено достоверное стимулирующее действие эфирного масла полыни солянковидной на рост колоний Escherichia coli $(\mathrm{p}<0,05)$ и Klebsiella pneumoniae (p < 0,01), индифферентное действие на рост колоний Staphylococcus aureus, Pseudomonas aeruginosa, Acinetobacter baumannii.

3. В анатомическом строении растений Artemisia salsoloides обнаружены признаки эфирномасличного растения: в мезофилле листа встречаются эфирномасляничные вместилища, в латеральных частях среза листа имеются 1-2 смоляных хода, в эндодерме стебля - секреторные каналы и в клетках хлоренхимы липидные капли.

\section{Список литературы}

1. Алякин А.А., Ефремов А.А., Качин С.В., Струкова Е.Г. Динамика выделения и компонентный состав эфирного масла тысячелистника обыкновенного пригорода Красноярска // Химия растительного сырья. 2009. №4. C. $73-78$.

2. Алякин А.А., Ангаскиева А.С., Ефремов А.А., Гребенникова В.В. Химический состав эфирных масел Artemisia absinthium L. и Artemisia vulgaris L., произрастающих на территории Красноярского края // Химия растительного сырья. 2011. №4. С. 115-120.

3. Водолазова С.В., Мяделец М.А., Карпова М.Р., Саранчина Ю.В. Антимикробная активность эфирных масел и водных извлечений из лекарственных растений Хакасии // Сибирский медицинский журнал. 2011. Т. 26. №2. C. 54-58.

4. Burt S.A. Essential oils: their antibacterial properties and potential applications in foods: a review // Inter. J. Food Microbiol. 2004. Vol. 94. Pp. 223-253.

5. Kotan R., Mavi A. Determination of the chemical composition and antioxidant activity of the essential oil of Artemisia dracunculus and of the antifungal and antibacterial activities of Turkish Artemisia absinthium, Artemisia dracunculus, Artemisia santonicum and Artemisia spicigera essential oils // J. Agric Food chem. 2005. Vol. 53. Pp. 9452-9458.

6. Sylvestre M., Pichette A., Longtin A. Essential oil analysis and anticancer activity of leaf essential oil of Croton flavens L. from Guadeloupe // J. Ethnopharmacol. 2006. Vol. 103. Pp. 99-102.

7. Супильникова А.В., Супильников А.А. Фитохимическое исследование травы полыни эстрагон и возможности применения препарата на ее основе в медицинской практике // Науки о человеке: сборник статей молодых ученых и специалистов. Томск, 2002. С. 254.

8. Сульдина А.Ф., Ефремов А.А., Некрасова В.Д. Санационные свойства эфирных масел некоторых дикорастущих растений Сибири // Вестник КрасГАУ. 2006. №10. С. 327-331.

9. Карташова О.Л., Ткачев А.В., Уткина Т.М., Потехина Л.П. Влияние эфирных масел полыни на рост микроорганизмов и образование ими биопленок // Бюллетень Оренбургского научного центра УрО РАН. 2012. №3. C. $2-10$. 
10. Киселева К.В., Майоров С.Р., Новиков В.С. Флора средней полосы России: Атлас-определитель. М., 2013. $544 \mathrm{c}$.

11. Васильев А.Е., Воронин Н.С., Еленевский А.Г. и др. Морфология и анатомия растений. М., 1988. 480 с.

12. Ткачев А.В. Исследование летучих веществ растений. Новосибирск, 2008. 969 с.

13. Adams R.P. Identification of essential oil components by gas chromatography/mass spectrometri. Carol Stream, 2006. $804 \mathrm{p}$.

14. Патент № 2410437. Способ определения бактериостатического, бактерицидного и стимулирующего действия антибиотика на рост микроорганизмов / Л.С. Тирранен, В.Н. Торотенкова, Т.Б. Сказка / 27.01.2011.

15. Тирранен Л.С. Роль летучих метаболитов в межмикробном взаимодействии. Новосибирск, 1989. 104 с.

16. Лакин Г.Ф. Биометрия: учебник для вузов. М., 1990. 352 с.

17. Великородов А.В., Морозова Л.В., Пилипенко В.Н., Ковалев В.Б. Химический состав эфирного масла четырех эндемичных видов полыни Астраханской области: Artemisia lerchiana, Artemisia santonica, Artemisia arenaria и Artemisia austriaca // Химия растительного сырья. 2011. №4. С. 115-120.

18. Бодоев Н.В., Базарова С.В., Покровский Л.М., Намзалов Б.Б., Ткачев А.Б. Компонентный состав эфирного масла полыни холодной флоры Бурятии // Химия растительного сырья. 2000. №3. С. 41-44.

19. Методические указания «Определение чувствительности микроорганизмов к антибактериальным препаратам» // Клиническая микробиология и антимикробная химиотерапия. 2004. Т. 6. №4. С. 306-359.

20. Самойлова Г.В. Трапезников С.В. Оценка антибактериального действия настоев Artemisia L. // Естественные науки и экология. Омск, 2006. Вып. 10. С. 53-54.

Поступило в редакиию 5 декабря 2016 г.

После переработки 3 февраля 2017 г. 
Lapkina E.Z. ${ }^{1 *}$, Zaharova T.K. ${ }^{2}$, Tirranen L.S. ${ }^{l}$ COMPONENT COMPOSITION OF ESSENTIAL OIL OF ARTEMISIA SALSOLOIDES WILLD AND ITS ANTIMICROBIAL PROPERTIES

${ }^{I}$ Federal Research Center: Krasnoyarsk Scientific Center, Siberian Branch of the Russian Academy of Sciences,

ul. Akademgorodok, 50, Krasnoyarsk,660036 (Russia), e-mail: e.z.lapkina@mail.ru

${ }^{2}$ Krasnoyarsk State Medical University Professor V.F. Voino-Yasenetsky, ul. Partizana Zheleznyaka, 1, Krasnoyarsk, 660022 (Russia)

The purpose of this work - definition of component structure, the antimicrobial properties of an essential oil and detection of anatomic features of stalks and leaves of plants of Artemisia salsoloides.

Plants of Artemisia salsoloides collected in the Volgograd region on valleys of the rivers Ilovli and Don. The essential oil was taken by method of an exhaustive water steam distillation, and its component structure was determined by chromatography-mass spectrometry method.

The antimicrobial activity on an essential oil was estimated on reaction of test bacteria (Acinetobacter baumannii, Escherichia coli, Klebsiella pneumoniae, Pseudomonas aeruginosa, Staphylococcus aureus) in 5-fold repetitions on a difference in sizes of diameter of colonies of the test bacteria in experience and the control (the test bacteria connected from $0,5 \mathrm{ml}$ of distilled water).

As a result of researches as a part of an essential oil 24 components among which prevail are found: limonene $(34,8 \%)$, trans- $\beta$-ocimene $(20,4 \%)$ of cis- $\beta$-ocimene $(12 \%), \alpha$-pinene $(7,2 \%), \beta$-myrcene $(6,3 \%), \beta$-pinene $(6,2 \%)$. The reliable stimulating action of an essential oil on the growth of colonies is revealed of Escherichia coli $(p<0,05)$, Klebsiella pneumoniae $(p<0,01)$, inert action - on the growth of colonies of Staphylococcus aureus, Pseudomonas aeruginosa, Acinetobacter baumannii. Anatomic features of a stalk and the sheet Artemisia salsoloides Willd are revealed: the resin duct in the lateral parts of the leaf, secretory channels in a stalk endoderm, essential-oil containers in a leaf mesophyll, lipide inclusion in cells chlorenchyma.

Keywords: Antimicrobial activity of the essential oil, wormwood saltwort, plant anatomy.

\section{References}

1. Aliakin A.A., Efremov A.A., Kachin S.V., Strukova E.G. Khimiia rastitel'nogo syr'ia, 2009, no. 4, pp. 73-78. (in Russ.).

2. Aliakin A.A., Angaskieva A.S., Efremov A.A., Grebennikova V.V. Khimiia rastitel'nogo syr'ia, 2011, no. 4, pp. 115120. (in Russ.).

3. Vodolazova S.V., Miadelets M.A., Karpova M.R., Saranchina Iu.V. Sibirskii meditsinskii zhurnal, 2011, vol. 26, no. 2, pp. 54-58. (in Russ.).

4. Burt S.A. Inter. J. Food Microbiol., 2004, vol. 94, pp. 223-253.

5. Kotan R., Mavi A. J. Agric Food chem., 2005, vol. 53, pp. 9452-9458.

6. Sylvestre M., Pichette A., Longtin A. J. Ethnopharmacol., 2006, vol. 103, pp. 99-102.

7. Supil'nikova A.V., Supil'nikov A.A. Sb. statei molodykh uchenykh i spetsialistov «Nauki o cheloveke». [A collection of articles by young scientists and specialists in the "Science of Man"]. Tomsk, 2002, p. 254. (in Russ.).

8. Sul'dina A.F., Efremov A.A., Nekrasova V.D. Vestnik KrasGAU., 2006, no. 10, pp. 327-331. (in Russ.).

9. Kartashova O.L., Tkachev A.V., Utkina T.M., Potekhina L.P. Biulleten' Orenburgskogo nauchnogo tsentra UrO RAN, 2012, no. 3, pp. 2-10. (in Russ.).

10. Kiseleva K.V., Maiorov S.R., Novikov V.S. Flora srednei polosy Rossii: Atlas-opredelitel'. [The flora of the middle zone of Russia: the Atlas-determinant]. Moscow, 2013, 544 p. (in Russ.).

11. Vasil'ev A.E., Voronin N.S., Elenevskii A.G. i dr. Morfologiia i anatomiia rastenii. [Morphology and anatomy of plants]. Moscow, 1988, 480 p. (in Russ.).

12. Tkachev A.V. Issledovanie letuchikh veshchestv rastenii. [Investigation of volatile substances of plants]. Novosibirsk, 2008, 969 p. (in Russ.).

13. Adams R.P. Identification of essential oil components by gas chromatography/mass spectrometri, Carol Stream, 2006, $804 \mathrm{p}$.

14. Patent 2410437. 27.01.2011. (in Russ.).

15. Tirranen L.S. Rol' letuchikh metabolitov v mezhmikrobnom vzaimodeistvii. [The role of volatile metabolites in intermicrobial interaction]. Novosibirsk, 1989, 104 p. (in Russ.).

16. Lakin G.F. Biometriia: uchebnik dlia vuzov. [Biometrics: a textbook for high schools]. Moscow, 1990, 352 p. (in Russ.).

17. Velikorodov A.V., Morozova L.V., Pilipenko V.N., Kovalev V.B. Khimiia rastitel'nogo syr'ia, 2011, no. 4, pp. 115120. (in Russ.).

18. Bodoev N.V., Bazarova S.V., Pokrovskii L.M., Namzalov B.B., Tkachev A.B. Khimiia rastitel'nogo syr'ia, 2000, no. 3, pp. 41-44. (in Russ.).

19. Klinicheskaia mikrobiologiia i antimikrobnaia khimioterapiia, 2004, vol. 6, no. 4, pp. 306-359. (in Russ.).

20. Samoilova G.V. Trapeznikov S.V. Estestvennye nauki $i$ ekologiia. [Natural sciences and ecology]. Omsk, 2006, vol. 10, pp. 53-54. (in Russ.).

\footnotetext{
${ }^{*}$ Corresponding author.
} 